\title{
運転労働時間と運転行動について
}

\author{
Relationship between Drivers' Work Time and Conduct of Driving
}

\author{
関西医科大学 公秝衛生学教室 \\ 中迫幐 - 矢島信子 \\ Masaru Nakaseko and Nobuko Yajima \\ Department of Public Health, Kansai Medical School, Osaka
}

The objective of the present research is to examine the relationship between drivers' work time and conduct of driving. Research has been confined to the behavior of the drivers, the operation of the vehicle as well as the fatigue problem.

Results of questionaires distributed among 307 drivers are as follows :

(1) Operation of the vehicle (clutching, braking, accelerating, steering, gear shifting) were found to be independent of the drivers' work time.

(2) There appeared to be a close relationship between fatigue and frequent accidents on the $8.1 \sim$ $\mathrm{hr}$ /day driving. In addition there was a traffic accident tendency attributed to drowsiness of drivers under the $0 \sim 3.0 \mathrm{hr}$ /day driving.

(3) Many traffic accidents occured on 12-14, 14-16 o'clock, but these were independent from working time.

(4) Values (traffic accident frequency/drivers' work time) are presumed to be a better index than the frequencies themselves in order to correctly evaluate the survey of the specific relation between drivers' work time and conduct of driving.

\section{I 序論}

大都市への企業集中，また産業「合理化」政策などに より，自動車が交通運輸機関として果たす役割は増加し て来た。しかしてのような社会現象の中で, 交通量の増 大一交通過密化現象を生み, 同時にそれに対応すべき道 路条件, 交通安全施設の未整備などの条件が重なり, 自 動車事故を激増させている。このような交通現象に対し，

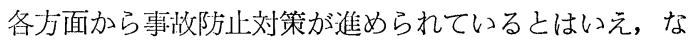
抒後手に回っているのが実状である。したがって現実に 有効な事故防止対策を進めるうえでも, 事故原因の科学 的究明は重要である。

事故発生件数の統計資料作成, 事故発生要因の調查研 究はいろいろの領域でいろいろの方法を用いて行なわ れているが, 自動車事故発生要因として, (1)車両行動, (2)交通環境，(3)運転行動に大別できる。そのうち車両行 動とは, たとえば右左折, 走行状態, 徐行, 停車, 急停 車, 車線変更などの行動があげら机，交通環境とは道路条
件，交通量，交通標識，横断施設などを，運転行動とは 自動車の運転操作のみならず運転時のあらゆる動作を含 む運転者の行動を示している。

本論では, 運転行動に重点を置いた。というのは, 交 通事故発生要因を追求する従来の調查は交通環境亡車両 行動との間の関係として実態を統計的に把握しょうとす るあのが多く, しかむその多くは警察事故統計に負うと ころが大きい。いうまであなく，交通事故による死亡統 計の方法, 事故の断面的分析いわゆる事故状況調査にす ぎない点に問題がある。すなわち交通環境は道路条件を 除いて, 流動的であり, 車両行動, 運転行動に至っては 事故発生以前の経時的な行動の变化, 運転者の生理的・ 心理的状態, 労㗢の質・量に低存した生活環境の上に成 り立っている。長時間運転労衔者に事故が多いといわれ ている事実加ら明らかなように，事故発生要因は自動車 の運転と運転学働時間との関係に捄いて, 調査, 考察され る必要があろう。運転行動とは自動車運転に必要な情報 を認知, 判断し, 車両を予測する正確な位置に連続的に 
移動させるととである。しかし, 実際の運転行動には, 上述のととに加え, 苛酷な学衝条件に上る生理的 - 心理 的負担を回避するために，たとえばタクシー運転労働者 にあっては，水揚高を上げるための効率的な乗客の選択 やスピード運転を刺激する社会的要因を考慮しなければ ならない。したがって, 交通事故発生要因を明らかにす るためには, 運転者の生活条件のなかで, 運転行動を評 価し事故との関連を究明しなければならない。

その一考察として, 運転学働時間と運転行動について 次のような調查を行なった。(1)各種の運転行動の自己評 定, (2)運転行動之疲労感について, (3)運転行動之事故・ 違反について調べた。

\section{III. 調 査 方 法}

1. 調査対象者; (1)交通事故経験者: 大阪北郊（門真 - 守口市域）において, 死亡あるいは負傷の程度が 2 週 間以上之「骖断」された「人身事故」で（a)追突事故の 加害者, (b)歩行者事故の加害者。いずれす別揭表 1 の調 査用紙を郵送配布し, 自由記入させた。その回収数は, (a)120名 (b)60名で回収率はそれぞれ47.6\%，48.3\%で あった。(2)職業運転者: ハイヤー・タクシ一運転者を対 象として各運転者50名に調查用紙を配布し, 記入後一括 回収した。完全記入者は44名であった。(3)運送業従事者 : 長距離運送, 近距離運送, 生コンクリート運送および タンクローリー運転者に対し，それぞれ 23 名, 32 名, 13 名, 15名を調查した。

2. 調査項目; 表 1 の調査用紙の通りであった。運転 技術の良否および運転中の外界刺激に対する反応評価は 7 件法の評定尺度 ${ }^{1), 2)}$ (rating scale) により, 運転者 の主観的評価を求めた。評定尺度の一極端を 1 , 他の極 端を 7 とし, 両極端のみをそれぞれ「非常に〜ない」あ るいは「まったく〜ない」と「非常に〜である」あるい は「まったく〜である」という尺度の評価を与え，その 間を 6 等分して, 適当と思われる数字に○印を記入さ せた。

その他の質問項目に関しては頻度で解答するように求 めた。

3. 結果の整理; 調查成績は一日当たりの運転労働時 間別に，一日当たり 0 3.0時間 (以下 $0 \sim 3.0 \mathrm{hr} /$ day と 略す), 一日当たり 3.1 8. 時間 (以下3.1 8. $0 \mathrm{hr} /$ day 之略す), 一日当たり 8.1 時間以上 (8.1 hr/day 之略 す)の 3 条件に分類, 整理した。また, 年齢, 運転経験 年数, 職業特性は調査対象(a), (b)のみについて整理した 結果である。その他の結果は全調査対象の結果である。

\section{表 1. 運転行動に関する調查表}

次の問にお答え下さい。

性別…男 女 年令 : 満 歳

住所——市————_町

1.あなたの運転経験年数——年

2. あなたの職業

3. あなたは 1 日（24時間）当何時間自動車を運転しま すか。

$0 \sim 2.1, \quad 2.1 \sim 3.0, \quad 3.1 \sim 5.0, \quad 5.1 \sim 8.0, \quad 8.1 \sim$ 12.0，12.1時間以上

4. 今まで事故をおこしたことがありますか。

$0,1,2,3,4,5$ 回以上

5. 過去 3 年間に交通違反を犯したととがありますか。 $0,1,2,3,4,5$ 回以上

6. あなたの犯した違反の種類を(二)で囲んで下さい。 信号無視, 速度違反, 飲酒運転, 徐行違反, 駐停車 違反, 一時停止違反, 右左折違反, 追越違反, 割込 違反, 登火違反, 車間距離不保持, 通行区分違反, 安全運転違反, 踏切通行違反, 優先通行違反, 歩行 者保護違反, 定員オーバー, 積載オーバー, その他

7. あなたはどんな車種におのりですか。 例 : コロナ 1500 .

8. あなたは休㮩なしで最高何時間位運転しましたか。 2 時間以内, $3,4,5,6,7,8,9,10$ 時間以上

9. あなたの運転技術はどれくらいだと思いますか。適 当と思うとてろに○印をつて下さい。

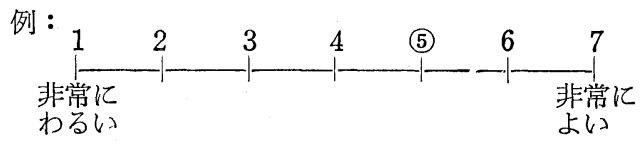

クラッチの操作

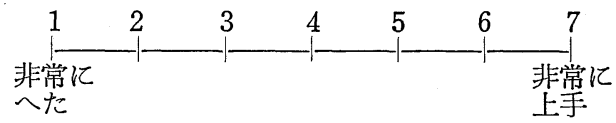

ブレーキの操作

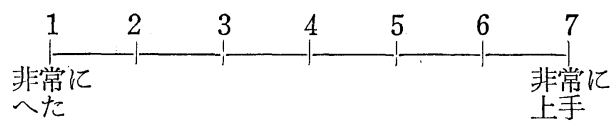

アクセルの操作

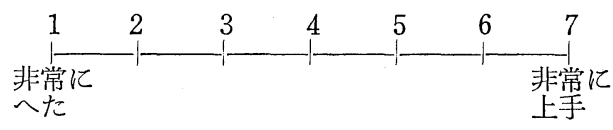

ハンドルの操作

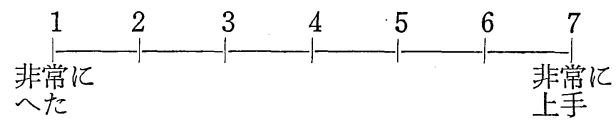


チェンジギャ一の操作

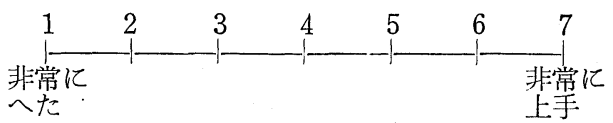

10. 総合するとあなたの連転はどのぐらいですか。

$\underset{\substack{\text { 非常に } \\ 1}}{1}$

11. 運転中；ブレーキをよく踏みますか。

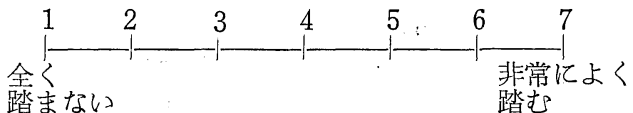

12.あなたはスピードを出しますか。

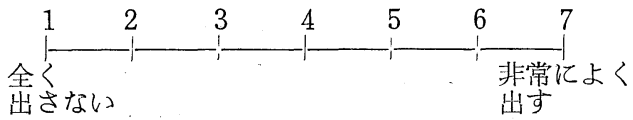

13. 交通量が少なくなればスピードを出しますか。

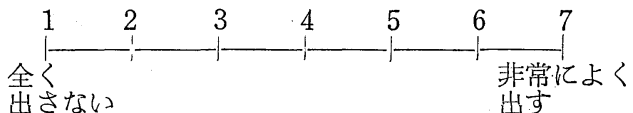

14.あなたは追越をしますか。

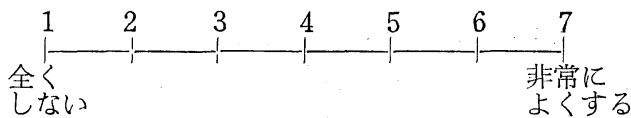

15.あなたは運転中サイドミラーをみますか。

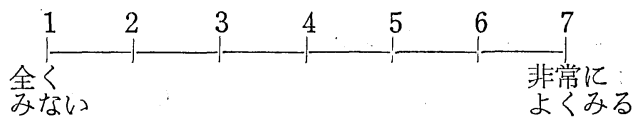

16.あなたは運転中バックミラーをみますか。

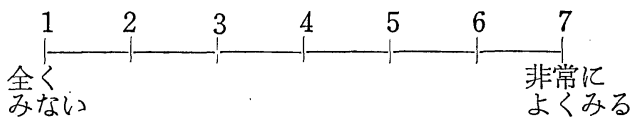

17. 道路わきで横断歩道を渡ろうとする人をみたとき, あなたは止まりますか。

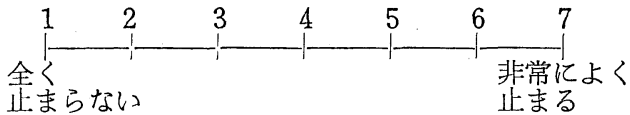

18.あなたは運転中，人のとび出しにより急ブレーキを かけたことがありますか。

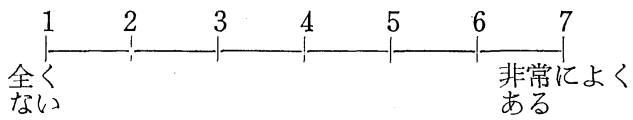

19.それはどのような場所ですか。

例えば 横断歩道

20、そのとき自分はスピードを出していたと思いますか。

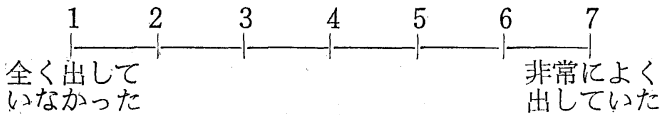

21、あなたは運転中夕バコを契いますか。

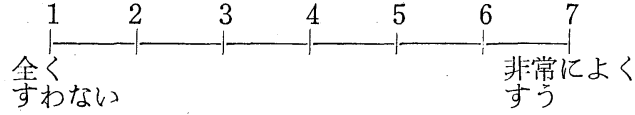

22. 同乗者があるとき，あなたの運転態度は变りますか。

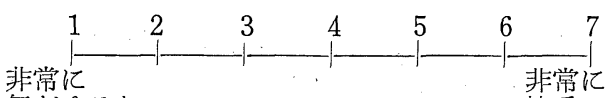

気がゆるむ慎重になる

23.あなたは走行中先行車のどの部分を一番注意します か。図の $A \cdot B \cdot C \cdot D$ を注意する順に並べて下さい。

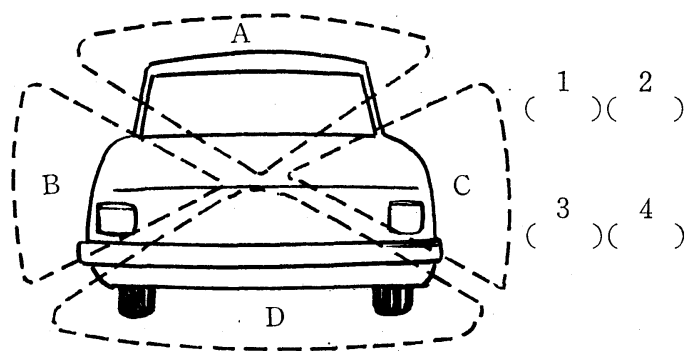

24. あなたが一番運転しにくいと思うのは何時ごろです 加。

午前・午後㭙から午前・午後時まで

25.あなたが運転しにくいと思う場所は具体的にどのよ うな所ですか。

例えば 小学校の前

26. あなたが運転していて一番眠くなるのは何時でろで すか。下記の中から三つ選んで○をつけて下さい。 $8-10$ 時, 10-12時, 12-14時, 14-16時, 16-18 時, 18-20時, 20-22時, $22-24$ 時, 0-2時, $2-4$ 時, 4-6 時, 6-8 時

27. あなたは運転を始めてから，何時間ぐらいたつと疲 れを感じますか。○をつけて下さい。

30 分 -1 時間， $1-2$ 時間， $2-3$ 時間，3-4 時間， $4-5$ 時間， 5-7 時間，7-10時間

28. あなたが運転を始めてから何 $\mathrm{km}$ ぐらい走ったとき， 疲れを感じますか。○をつけて下さい。 $25 \mathrm{~km}$ 以下, $50 \mathrm{~km}, 75 \mathrm{~km}, 100 \mathrm{~km}, 150 \mathrm{~km}$, $200 \mathrm{~km}, 300 \mathrm{~km}$ 以上

29. 何時頃運転するのが一番疲れを感じますか。，疲れる 順に 3 番まで番号をいれて下さい。

8-10時, 10-12時, 12-14時, 14-16時, 16-18 時, 18-20時, 20-22時, 22-24時, 0-2 時, 24 時, $4-6$ 時, 6-8 時 
III 調 査 成 績

1. 1 日当たりの運転学衝時間別にみた年齢, 運転経

Table 2. Distributions of driver's years on each working-time for driving.

\begin{tabular}{cc|c|c|c}
\hline $\begin{array}{r}\text { Working-time } \\
\text { for driving } \\
\text { hr/day }\end{array}$ & $0 \sim 3.0$ & \multicolumn{2}{|c|}{$3.1 \sim 8.08 .1 \sim$} \\
Years & & & & \\
\hline & $\sim 20$ & .05 & 0 & .01 \\
$21 \sim 25$ & .09 & .07 & .01 \\
$26 \sim 30$ & .28 & .24 & .19 \\
$31 \sim 35$ & .20 & .26 & .34 \\
$36 \sim 40$ & .17 & .20 & .19 \\
$41 \sim 45$ & .11 & .10 & .21 \\
$46 \sim 50$ & .03 & .03 & .04 \\
$51 \sim 55$ & .02 & .06 & .01 \\
$56 \sim 60$ & .03 & .02 & 0 \\
$61 \sim 65$ & .02 & .01 & .01 \\
$66 \sim 70$ & .02 & 0 & 0 \\
\hline Total & 65 & 100 & 101 \\
\hline
\end{tabular}

The tolal shows the number of samples.
験年数，職業特性

調查対象運転者の年令と運転労働時間との関係を表 2 の度数分布表に示した。運転者の年齢は31 35歳が最も 多く, それ以上または以下の年秢では, 減少する。とく に，26４5歳の運転者は全体の $85 \%$ を占めている。運転

Table 3. Frequency distribution of experiential years on each working-time for driving.

\begin{tabular}{c|r|r|r}
\hline $\begin{array}{c}\text { Working time } \\
\text { for driving } \\
\text { hr/day }\end{array}$ & $0 \sim 3.0$ & $3.1 \sim 8.08 .1 \sim$ \\
$\begin{array}{c}\text { Experi- } \\
\text { ential years }\end{array}$ & & & \\
\hline $0 \sim 1.9$ & 9 & 5 & 1 \\
$2 \sim 3.9$ & 19 & 18 & 7 \\
$4 \sim 5.9$ & 11 & 23 & 12 \\
$6 \sim 7.9$ & 9 & 11 & 15 \\
$8 \sim 9.9$ & 5 & 8 & 23 \\
$10 \sim 11.9$ & 7 & 11 & 13 \\
$12 \sim 13.9$ & 2 & 8 & 10 \\
$14 \sim 15.9$ & 2 & 4 & 13 \\
$16 \sim 17.9$ & 1 & 3 & 2 \\
$18 \sim$ & 0 & 11 & 6 \\
不 & 2 & 0 & 0 \\
& & &
\end{tabular}

Table 4. Distributions of self-rating value on driving operations compared with working-time for driving.

\begin{tabular}{|c|c|c|c|c|c|c|c|c|c|}
\hline $\begin{array}{r}\text { Working tim } \\
\text { for } d \\
\begin{array}{c}\text { Driving } \\
\text { operation }\end{array}\end{array}$ & $\begin{array}{l}\text { Rating } \\
\text { scal } \\
\text { ing day }\end{array}$ & 1 & 2 & 3 & 4 & 5 & 6 & 7 & Mdn. \\
\hline clutch & $\begin{array}{l}\quad 0 \sim 3.0 \\
3.1 \sim 8.0 \\
8.1 \sim\end{array}$ & $\begin{array}{l}.02 \\
.01 \\
.01\end{array}$ & $\begin{array}{l}.03 \\
.00 \\
.00\end{array}$ & $\begin{array}{l}.03 \\
.03 \\
.03\end{array}$ & $\begin{array}{l}.23 \\
.17 \\
.17\end{array}$ & $\begin{array}{l}.42 \\
.34 \\
.34\end{array}$ & $\begin{array}{l}.22 \\
.27 \\
.27\end{array}$ & $\begin{array}{l}.06 \\
.18 \\
.18\end{array}$ & $\begin{array}{l}4.96 \\
5.36 \\
5.36\end{array}$ \\
\hline brake & 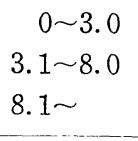 & $\begin{array}{l}.02 \\
.00 \\
.04\end{array}$ & $\begin{array}{l}.02 \\
.00 \\
.00\end{array}$ & $\begin{array}{l}.03 \\
.01 \\
.06\end{array}$ & $\begin{array}{l}.21 \\
.18 \\
.15\end{array}$ & $\begin{array}{l}.35 \\
.29 \\
.29\end{array}$ & $\begin{array}{l}.29 \\
.32 \\
.25\end{array}$ & $\begin{array}{l}.10 \\
.21 \\
.21\end{array}$ & $\begin{array}{l}5.16 \\
5.58 \\
5.56\end{array}$ \\
\hline accelerator & 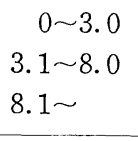 & $\begin{array}{l}.02 \\
.00 \\
.02 \\
\end{array}$ & $\begin{array}{l}.00 \\
.00 \\
.00 \\
\end{array}$ & $\begin{array}{l}.00 \\
.00 \\
.05\end{array}$ & $\begin{array}{l}.25 \\
.24 \\
.17\end{array}$ & $\begin{array}{l}.33 \\
.26 \\
.30\end{array}$ & $\begin{array}{l}.30 \\
.34 \\
.26\end{array}$ & $\begin{array}{l}.11 \\
.17 \\
.20\end{array}$ & $\begin{array}{l}5.23 \\
5.51 \\
5.37\end{array}$ \\
\hline steering-wheel & $\begin{array}{l}\quad 0 \sim 3.0 \\
3.1 \sim 8.0 \\
8.1 \sim\end{array}$ & $\begin{array}{l}.02 \\
.00 \\
.02 \\
\end{array}$ & $\begin{array}{l}.00 \\
.00 \\
.01\end{array}$ & $\begin{array}{l}.05 \\
.01 \\
.05 \\
\end{array}$ & $\begin{array}{l}.16 \\
.22 \\
.16\end{array}$ & $\begin{array}{l}.32 \\
.29 \\
.23\end{array}$ & $\begin{array}{l}.35 \\
.25 \\
.35\end{array}$ & $\begin{array}{l}.11 \\
.24 \\
.19\end{array}$ & $\begin{array}{l}5.38 \\
5.45 \\
5.61\end{array}$ \\
\hline gear-lever & $\begin{array}{l}\quad 0 \sim 3.0 \\
3.1 \sim 8.0 \\
8.1 \sim\end{array}$ & $\begin{array}{l}.02 \\
.00 \\
.02\end{array}$ & $\begin{array}{l}.00 \\
.00 \\
.01\end{array}$ & $\begin{array}{l}.06 \\
.02 \\
.06\end{array}$ & $\begin{array}{l}.21 \\
.25 \\
.15\end{array}$ & $\begin{array}{l}.29 \\
.24 \\
.25\end{array}$ & $\begin{array}{l}.35 \\
.28 \\
.27\end{array}$ & $\begin{array}{l}.08 \\
.22 \\
.24\end{array}$ & $\begin{array}{l}5.25 \\
5.48 \\
5.54\end{array}$ \\
\hline total rating & $\begin{array}{l}\quad 0 \sim 3.0 \\
3.1 \sim 8.0 \\
8.1 \sim\end{array}$ & $\begin{array}{l}.02 \\
.00 \\
.00\end{array}$ & $\begin{array}{l}.03 \\
.00 \\
.00\end{array}$ & $\begin{array}{l}.03 \\
.01 \\
.01\end{array}$ & $\begin{array}{l}.25 \\
.23 \\
.23\end{array}$ & $\begin{array}{l}.38 \\
.37 \\
.37\end{array}$ & $\begin{array}{l}.24 \\
.30 \\
.30\end{array}$ & $\begin{array}{l}.05 \\
.10 \\
.10\end{array}$ & $\begin{array}{l}4.94 \\
5.22 \\
5.22\end{array}$ \\
\hline
\end{tabular}


労働時間別にみると, $0 \sim 3.0 \mathrm{hr} /$ day では26 30歳が 28 $\%, 3.1 \sim 8.0 \mathrm{hr} /$ day では 31 35歳が $26 \% ， 8.1 \sim \mathrm{hr} /$ day では 31 35 歳が34\%で最頻值を示す。その平均値 は順に34.5歳, 35.4歳そして 36.0 歳で長時間運転労働従 事者ほど年齢が高い傾向を示している。

運転経験年数の分布は表 3 のごとくである。運転経験 年数を運転労働時間別に比較すると, $0 \sim 3.0 \mathrm{hr} / \mathrm{day}$ が $2 \sim 3.9$ 年, $3.1 \sim 8.0 \mathrm{hr} /$ day がが $4 \sim 5.9$ 年, $8.1 \sim \mathrm{hr} /$ day が8 9.9年に分布の頂点を持ち，その平均值は順に 5.3 年, 7.9 年, 9.3 年であった。このととから, 運転労働に 要する時間が多い職業に従事する運転者ほど経験年数が 長いととがわかる。

運転労働時間別に 職業特性をみると， $0 \sim 3.0 \mathrm{hr} /$ day では, 建設業従事者が $21 \%$ で最む多く, トラック運転者 とサービス業従事者がいずれあ13\%でてれに次いでいる。 $3.1 \sim 8.0 \mathrm{hr} /$ day では, トラック運転者が $22 \%$, 卸売・ 小売業従事者 $21 \%$ ，製造業從事者 $15 \%$ の順に多い。 8.1 $\sim \mathrm{hr} /$ day では, トラック運転者 $45 \%$, タクシー運転者 $23 \%$ ，他の職業貨物運転者 $13 \%$ の順に多い。なお，職業 特性に関しては前記の特定事業所に勤務する運転者を含 んでいない。

\section{2. 運転行動の自己評価}

表 4 は運転学働時間別に各運転操作項目について, 評 定された結果を示している。どの項目に関しても, 評定 点 5 ６亿最頻値をむち，「非常に上手」である傾向を示 している。運転労㗢時間別にみると, $3.1 \sim 8.0 \mathrm{hr} /$ day, 8.1 hr/day は 0 3. 0hr/day に比較して, どの操作項 目と屯,評定は「非常に上手」である傾向が強く,とくに クラッチ, アクセル, ブレーキの各操作にその傾向がみ られる。しかし，ハンドル，チエンジ・レバーの操作に はその傾向がみられない。次に, 総合した運転操作の評 定をみると，0 3.0 hr/day は他の条件に較べて, 評定 值の Mdn (Median) は低い。

運転操作は個々の操作の算術総和ではないが運転技術 としては重要であろう。運転操作が手と足との協応動作 であるととを考えれば， 1 日当たり運転労㗢時間の短い 条件にクラッチ，アクセル，ブレーキなどの足による操 作が低い評定値を示していることは興味あるととである。

\section{3. 運転行動と「疲労」}

「一番眠たくなる」時間帯を時刻の関数として図示す ると, 図 1 の通りである。0 3.0 hr/day, $3.1 \sim 8.0 \mathrm{hr} /$ day, 8.1 hr/day の各条件とむ，14 16時に最む「眠 気」を感じ，その他の時間帯では，条件間に著しい差は 認められない。
また，「疲れを感ずる」時間帯について，全体的傾向 を時刻の関数として分布を図示（図 2) すると，「疲れ を感ずる」時間帯はいずれの条件のばあいす，14 16時 が16〜18時がピークである。とくに深夜に「疲れを感ず る」あのは長時間運転者に多い。各条件内の比較は次の 通りである。すなわち，0 3.0 hr/day では，16 18時， 14 16時, 18〜20時, 12 14時に「疲れを感ずる」と答 え, $3.1 \sim 8.0 \mathrm{hr} /$ day では, 16 18時, 14 16時の時間 帯に「疲れを感ずる」傾向が著しい。8.1 hr/dayでは, 22 24時，0２時，2４時，16１8時により多く「疲れ を感じている」。したがって，薄暮の16１8時には，「痩 れ」之「眠気」之が同時に出現し, 自動車を運転する学 働者にとって, 潜在事故頻発時間である。1日当たりの運 転時間の長さが特異な傾向を示す時間は $0 \sim 3.0 \mathrm{hr} /$ day

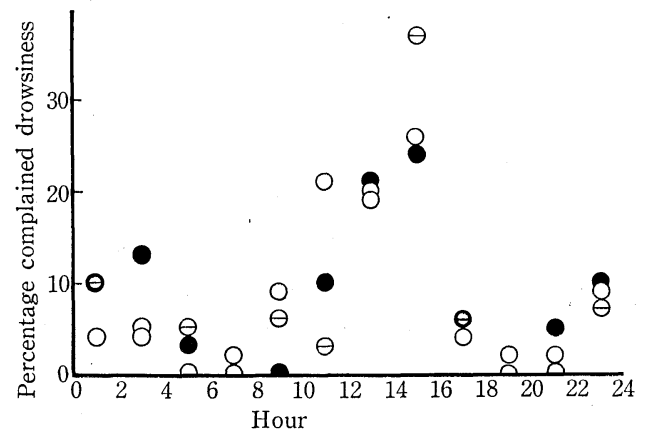

Fig. 1 The drowsiness complained as function of hour $0: 0 \sim 3.0 \mathrm{hr} /$ day, $\ominus: 3.1 \sim 8.0 \mathrm{hr} / \mathrm{day}, 0: 8.1 \sim \mathrm{hr} / \mathrm{day}$

The curves of the drowsiness plat for a midpoint of class-interval time.

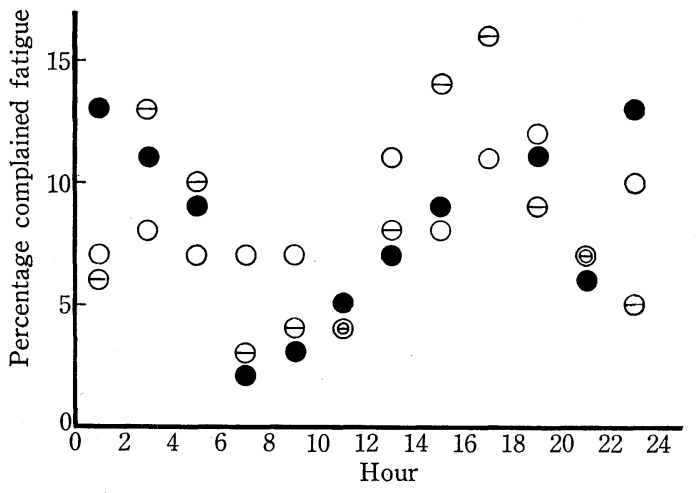

Fig. 2 The fatigue complained as function of hour O : $0 \sim 3.0 \mathrm{hr} /$ day, $\Theta: 3.1 \sim 8.0 \mathrm{hr} /$ day, : $8.1 \sim \mathrm{hr} / \mathrm{day}$ The curves of the fatigue plat for a midpoint of class-interval time, 
の $22 \sim 24$ 時, $3.1 \sim 8.0 \mathrm{hr} /$ day および $8.1 \sim \mathrm{hr} /$ day の $0 \sim 2$ 時である。

次に, 運転を始めてから, 「疲れ」の出現する出現時 間, 出現距離の分布を運転時間, 運転距離の関数として 図示すると, 図 3 , 図 4 の通りである。0 3.0 hr/day および $3.1 \sim 8.0 \mathrm{hr} /$ day のばあいは運転開始 3.1 4.0 時間後にまた走行距離については101〜150kmで, 8.1 $\mathrm{hr} /$ day のばあいでは4 5時間後, 150 200km で，「疲

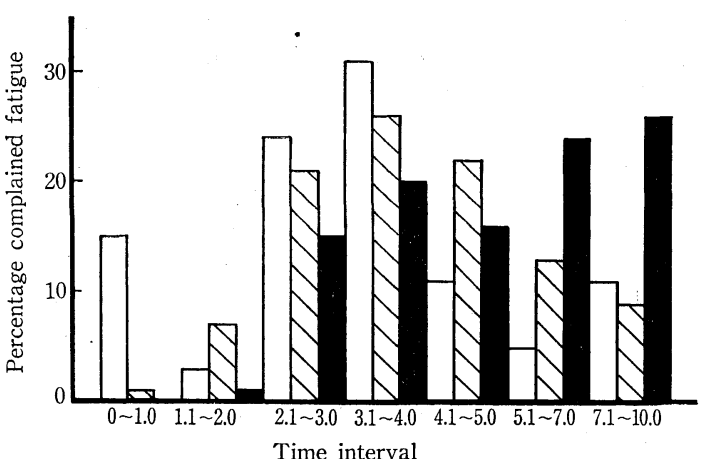

Fig. 3 Distributions of driving time complained fatigue $\square: 0 \sim 3.0 \mathrm{hr} /$ day $\mathbb{N}: 3.1 \sim 8.0 \mathrm{hr} /$ day $\square: 8 \sim \mathrm{hr} /$ day

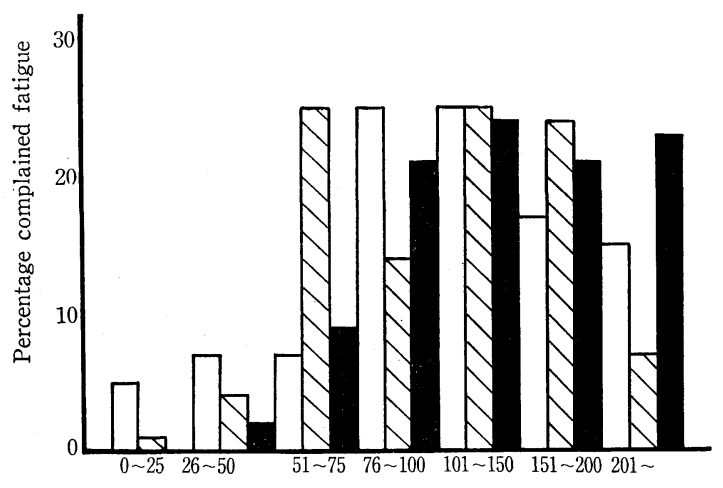

Running distance $(\mathrm{Km})$

Fig. 4. Distributions of running distance complained fatigue $\square: 0 \sim 3.0 \mathrm{hr} /$ day $\mathbb{N}: 3.1 \sim 8.0 \mathrm{hr} /$ day $\mathbf{\square}: 8.1 \sim \mathrm{hr} /$ day
労」感の出現を示す。1 日当たりの運転時間が長くなる と, 分散が大きく, 個人差が認められる。とくに，8.1 $\sim \mathrm{hr}$ /day では, 4 5 時間, $200 \mathrm{~km}$ を境に, 「疲労」 に対する評定尺度に差が認められる。すなわち，「疲労」 に対し与えられる評価の質的, 量的要因を異にする二つ の型,「疲労」に対し感受性の低い型と高い型に分類さ れる。

以上の結果加ら, 日常の運転条件之無関係に, 運転学 働者は12 18時の時間帯に「眠気」と「病労」とを同時 に感じている状態があり, 運転労働時間による「疲労」 と「眠気」の差は深夜の運転に認められる。タクシ一, 長距離運送の運転労働者にとの傾向が強く, とくに, $2 \sim 4$ 時に非常に多く, $13 \%$ が疲学感を訴えている。乙 の差は運転労働者の生活時間のちがいにあり, 樑夜に高 速運転するタクシ一運転者にとって, 事故潜在要素の多 い時刻である。つまり，一乗務18～19時間拘束，14時間 運転の労働条件のもとでは, 疲労性機能低下が著しく, この低下が運転行動に色険な結果を予期させるに充分で あるととを示している。

\section{4. 運転行動と事故}

運転学働時間別に，運転行動と運転時のその他の圥長 的行働之交通事故・交通違反との関係をみると次の通り である。

表 5 は交通事敌・交通違反を運転学㗢時間別に比較し た結果である。1日当たり運転時間が長いほで事故回数 は多いが，単位時間当たりの事故回数は運転労働時間が 長いほど少ない。8.1 hr/day では, 事故歴 3 回以上の 事故頻発者が42\%を占め, 他の群に比して著明に多い。 しかし, 事故発生自体は運転時間要素からみ机ば, 確率 的要素を多分に含んでいる。

また, 過去 3 年間に発生した「交通違反」の傾向は運 転労㗢時間が短いほど, 違反回数および単位時間当たり の違反回数と屯に増加する。しかし，交通違反の傾向を 違反回数の関数で示すと(表 5 )，0 3.0 $\mathrm{hr} / \mathrm{day}, 8.1$

Table 5. Distributions of traffic accident and traffic violation on three different working-time for driving per day.

\begin{tabular}{|c|c|c|c|c|c|c|c|c|c|c|c|c|c|c|c|}
\hline \multirow[b]{2}{*}{$\mathrm{hr} /$ day } & \multirow[b]{2}{*}{$\begin{array}{c}\text { Frequencies of } \\
\text { traffic accident }\end{array}$} & \multicolumn{6}{|c|}{ Traffic Accident } & \multirow[b]{2}{*}{ A. R.* } & \multicolumn{6}{|c|}{ Traffic Violation } & \multirow[b]{2}{*}{ V.R.**: } \\
\hline & & 0 & 1 & 2 & 3 & 4 & $5 \sim$ & & 0 & 1 & 2 & 3 & 4 & $5 \sim$ & \\
\hline & $0 \sim 3.0$ & .02 & .68 & .18 & .08 & .02 & .03 & 1.11 & .23 & .39 & .17 & .09 & .05 & .08 & 1.10 \\
\hline & $3.1 \sim 8.0$ & .11 & .50 & .27 & .09 & .02 & .01 & .41 & .31 & .27 & .21 & .13 & .07 & .01 & .38 \\
\hline & $8.1 \sim$ & .07 & .30 & .22 & .20 & .06 & .16 & .26 & .32 & .33 & .14 & .09 & .06 & .06 & .17 \\
\hline
\end{tabular}

*Accident ratio $=($ median of frequencies of accident $) /($ mean of the working-time for driving $)$

**Violative ratio $=$ (median of frequencies of violation) $/$ (mean of the working-time for driving) 
hr/day は類似した分布型を示し,違反 2 回以下がいずれ の群む79，台を占め，それ以上では急激な減少傾向を示す。 $3.1 \sim 8.0 \mathrm{hr} /$ day では, 多数回違反者が多く, 違反 2 问 以上の者は $42 \%$ を占めている。これら結果を職業特性之 の関連に扎いてみると，大型トラックの事故・違反率は 運転労働時間之関係なく, 全般に高い。，0〜3.0 hr/day は蹅転を労衝そのものとしているあのは少なく，ほとん ぞが通勤・作業現場への通勤であり，3.1〜8.0，8.1〜 $\mathrm{hr} /$ day では，自動車の運転が労働の一部あるいはすべ てであり, 長距離・地場運送，八イタク，卸売・小売の 商品運搬のように車の移動範囲は大きく, また，市内の 狭路通行が多い。そのため, 一時停止, スピード違反が 多いといえる。

表 6 は 1 日当たり運転労働時間別に，運転行動につい ての結果である。「運転中，ブレ一キを踏みますか」(Q： 11）に対し，0〜3.0hr/day は，他の 2 条件に較べて, ややブレーキをよく踏む傾向を示した。「あなたはスピ ードを出しますか」(Q.12) に刘し，0〜3.0hr/day に比 較して, 3.1 8. $0 \mathrm{hr} /$ day の評定値の Mnd. は大きく, $0 \sim 3.0 \mathrm{hr} /$ day は評定值 4 で $29 \%$ ，3.1 8.0 hr/day, 8.1 hr/day は評定值 5 でそれぞれ33\%，26\%である。 「交通量が少なくなれば，スピードを出しますか」（Q. 13）では，8１～hr/day のほとんどの運転者がよりス ピードを出し，その割合は $50 \%$ 亿ぶ゙。また $3.1 〜 8.0 \mathrm{hr}$ /day の運転者は $0 \sim 3.0 \mathrm{hr} /$ day に比較しよりスピード を出している。したがって，運転労働時間がスピードと 関係しており，労働条件が運転行動に影響を与えている といえる。交通事故発生の誘発原因の一つといわれてい る追越をみると，3.1〜8.0，8.1〜，0〜3.0hr/day の順 によく追越をし，3.1 8.0 hr/day には中型貨物，乗用 車などの車種が多く認められ, 後者には, 長距離運送従 事者が多い。乙れは長距離運送のほとんどが大型貨物車 のため，機動性にそしいためであり，車種の機能の反胦 された結果であるといえよう。

サイド・ミラー (Q.15), バック・ミラー (Q.16) は 後方の車両行動に関する情報を得る唯一の手段であるが, ほとんど運転者がサイド・ミラーを非常によくみており，

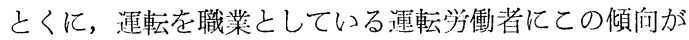
顕著である。バック・ミラーについても， 8.1〜hr/day を除いて，サイド・ミラーの絬果と同様の傾问を示す。 8.1〜hr/day では，「バック・ミラーを見ていない」と 答えた者が多い。つまり，ミラーを非常によく見るタイ プには, タクシー運転者に，それ以外のタイプには，長 距離，地場運送の運転者に多いが，これは，車種上，貨 物積載のため, バック・ミラーによる後方確認は不可能
になるためと考えられる。いずれにしてあ両ミラーとす に後方の車両行動の確認に充分利用され, 重要な情報供

Table 6. Distribution of self-rating value on the driving behavior from $Q 11$ to $Q 21$.

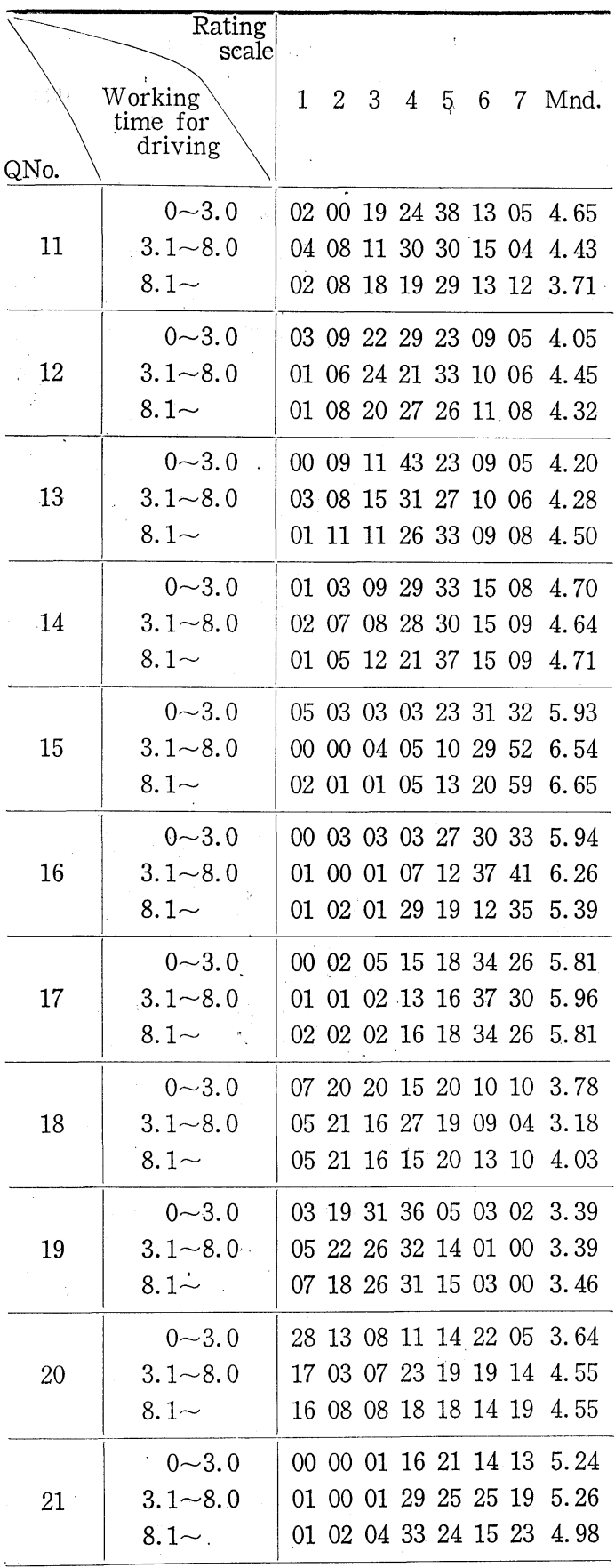

*The values of this table show the ratio to each $\mathrm{Q}$. 
給手段となっている。

次に, 横断歩行者之運転行動之の関係をみると, 道路 脇に立っている横断歩行者を認知したとき停止するか (Q.17), 人の跳び出しにより急停車したことがあるか (Q.18)，そのとき，スピードを出していたか（Q.20） の評定尺度の中央值は表 6 亿示す通りである。

Q.17，18，20 については，いずれも運転労働時間の 間に差は認められず，Q.18 を除いてほとんど類似した 傾向を示している。運転労働時間が増加するにつれ，走 行中, 人の跳び出しにより, 急制動した経験回数はやや 増加する。また，急制動を経験した場所はほとんど路地， 信号のない交差点や商店街である。次に走行時の前方注 意が先行車のどの部分により集中されるかは, 前方の車 両行動を予測する上に重要な運転行動の一つである。横 式図の先行車を四区分し，より注意する部分を求めた。 表 7 は先行車の各区分別に, 上位 2 位までの総計の相対 頻度の比率を示している。乙れによると, 運転者は運転 労㗢時間の差に関係なく, 先行車の両端に注意を集中し ている。すなわち, 先行車の車両行動の情報源之なる制 動灯, 方向指示器などの部分に注意がより向りられてい る。

Table 7. Part of preceding car paid attention by driver.

\begin{tabular}{c|c|c|c}
\hline $\begin{array}{c}\text { Working-time } \\
\text { for driving } \\
\text { hr/day }\end{array}$ & 0 3.03.1 8.08.1 \\
$\begin{array}{c}\text { Part of } \begin{array}{c}\text { of } \\
\text { preceding car }\end{array} \\
\text { A (upper) }\end{array}$ & .19 & .10 & .14 \\
B ( left ) & .32 & .38 & .40 \\
C (right) & .38 & .38 & .35 \\
D (down) & .11 & .14 & .11 \\
\hline
\end{tabular}

さらに，運転操作以外の行動で，「運転中，たばこを すいますか」(Q.20) の質問では, 運転労働時間が長く なればなるほど，たばこをすっており，「まったくすわ ない」者は 0 3. $0 \mathrm{hr} /$ day $28 \%, 3.1 \sim 8.0 \mathrm{hr} /$ day $17 \%$, 8.1 hr/day $16 \%$ あ゙あ。「同乗者があるとき，運転態 度は変わりますか」(Q.21) に対し，いずれの条件む， やや慎重になる傾向か認められる。長時間運転労働者の 場合, 態度に変化の認められない群と非常に慎重になる 群があり，てれらはサンプル集団の質を表わしている。

以上の結果が示すように, 長時間運転労働者の単位時 間当たりの事故率，違反率は最小であるにあかかわらず， 事故数が多い。このととはよく追越し，交通量が少なく なれば，よりスピードを出し，たばてを比較的よくすう ために，喫煙のための動作による運転外行動にも帰因し ている。事故回数と違反回数とは反比例の関係にあるが,
単位時間当たりに変換すれば，違反を繰返す者はまた雨 故む多発する傾问を持つといえる。彼らはブレーキをよ く踏み,交通量が少なくなればスピードを出し，サイド・ ミラー, バック・ミラーは他の条件に比洨してあまり見 ないような蹅転行動を特徵とし，とくに，足の操作によ る渾転行動に欠点があるといえる。

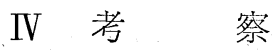

以上の結果の検討汃ら, 運転行動の自己評定, 疲労, 交通違反・事故は運転労㗢時間之密接な関係がある。す なわち, 車両行動, 運転行動は運転労働時間に依存して いるととが明らかである。

大阪府警の交通事故統計 ${ }^{3)}$ (昭和44年度) の「第一原 因者 (多くは加害者)」の事故内観報告によれば，判断 の誤り, 認知の遅れ, 行為的障害などにおける内観要素 は乗用車, 貨物車運転者と屯に同様の傾向を示し,「ほ かのてとに気をとられていた」(14.5\%；16.0\%)，「こ の程度注意すればよいと思った」(16.7\%；17.1\%), 「認知の遅れや判断の誤り」(37.6\%; $37.4 \%)$ などが内 観の大半を占めている。このととは運転行動が予測行動 であるととと同時に，運転操作のみならず，圥長的行動 を伴うことを示している。したがって，でのような行動 の規定因としての運転学働時間は交通事故発生および交 通違反頻発に重要な意味をむっている。

運転操作の技術評価は, 例外なく, 評定者の主観的評 価で表わされている。主観的評価方法は(1)第三者による (2)自己評価による方法に分けられる。前者は自動車運転 教習所や自動車運転試験所などで行なわれている「評定 者」による技術評価である。現行の運転技術の合否判定 法の問題は別として, 現行制度下では,一旦, 運転免許証 を交付されたあのの運転技術の再評価はほとんど行なわ れていない。評定尺度法に問題点 ${ }^{1,2)}$ を残しているとは いえ，一つの運転技術評価法である。各運転操作の評定 尺度に過大評価すなわち自己のもつ技術への過信の傾向 がある。それは総合評定が各操作の平均中央值より低い 值を示していることからあ明らかである。ただ，0〜3.0 $\mathrm{hr} /$ day に执いて，足による操作がやや劣る傾向がみら れ，予期に刘応した動作の遂行に不連続な点があると考 えられる。したがって, 実運転経験年数, 軍転学働時間 を考慮した運転操作の再評価が未然の事故防止対策とし て取り上げられる必要があろう。同時に，主観的偏向を 是正するための適切な自己評定法を考案する方法屯考え ねばならない。

次に, 運転行動による「疲労」は生理的・心理的機能 
の低下, 主として(1)外界刺激に注意を集中し, 即時的認 知, 即時的判断機能を維持するための連続的緊張 ${ }^{4)}$, (2) 一定の運転姿勢を保持する筋肉緊張, (3) 運転時の健康 ${ }^{5)}$

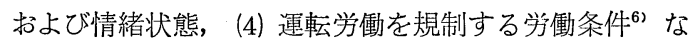
どと密接な関係がある。これらの生理的・心理的機能の 低下は局所機能, 例えば, 視機能, 反射機能飞出現する のみならず，大脳皮質を含む全身の活動の低下 ${ }^{7)}$ として 現われ，身体感覚的に自覚症状として評価されている。 生理心理学 (psycho-phgsiological) 的には, 心拍数, 筋 電図, 呼吸数, 血圧などの生理的反応を測定し, その機 能低下を生理的負担という形の相対量で示されているが, 「疲労」の実体は明らかでなく,「疲労」そのものの測定 は不可能である。しかしながら, 確かに, 「疲労」といわ れている種々の症状, 感覚を訴え, 評定している。つま り, 「疲労」は全体的な心身機能に対する感覚尺度上の 評価として把握でき, 感覚尺度上の一点として表わされ る主観的評価は生理的機能のみならず，心理的機能の低 下に対し，多次元的に評価された疲労特性の一つである。 このような考えに基づいて，「疲学」，「眠気」，「疲労」 の出現時間㧍よび出現距離と交通事故発生状況との関係 を検討した。

交通事故統計洔間別（2 時間間隔）交通事故発生状 沉之時間別 (上述之対応した時間間隔). 疲学訴え状沉 （Q.29）との関係は図 5 の通りである。相関係数 $\mathrm{r}$ を 求める之, $0 \sim 3.0 \mathrm{hr} /$ day では $\mathrm{r}=.21,3.1 \sim 8.0 \mathrm{hr} /$ day では $\mathrm{r}=.92$ 8.1 hr/day $\mathrm{r}=.63$ であった。同様に, 時間別事故発生状況上時間別眠気発生状況（Q. 26）之 の相関は $0 \sim 3.0 \mathrm{hr} /$ day $\mathrm{r}=.54,3.1 \sim 8.0 \mathrm{hr} /$ day $\mathrm{r}=$ .32, 8.1 hr/day $\mathrm{r}=.13$ であった。ただし，2-4，4 -6 時の深夜, 早朝時, および 8-10, 10-12 時は交通 環境たとえば交通量や心身状態（疲学, 眠気の訴え）な どが極端な傾向を示すため, 前述の時間带を除外し, $\mathrm{r}$ を算出した。長時間運転労㣫者では,「交通事故」と「疲 労」との間に密接な関係が認められるが, 短時間運転者 の相関は低い。長時間運転学働者には長距離運送, タク シ一運転を職業とするあのが多く, 細川 $\prod^{52,6\rangle}$ らの調査に よれば, 両者ともに労働時間は 16 19 時間で, 夜間勤 務, 睡眠不足で疲労蓄積状態に近い身体状態にあるとい われているととを考えれば, 事故発生と運転瘦労との関 係は成立するであろう。とくに, 「疲労」の訴え, 眠気 の訴えが非常に多くなる時間帯の 12 14 時, 14 16 時 では, 事故発生数は運転労働時間に関係なく多い。ま た, 8 10 時, 10 12 時は「疲労」の訴えと比較して事 故発生数がとくに多く, $2 \sim 4$ 時, $4 \sim 6$ 時の深夜運転は 「疲労」の訴え数が高いのに比較して, 事故発生数はと

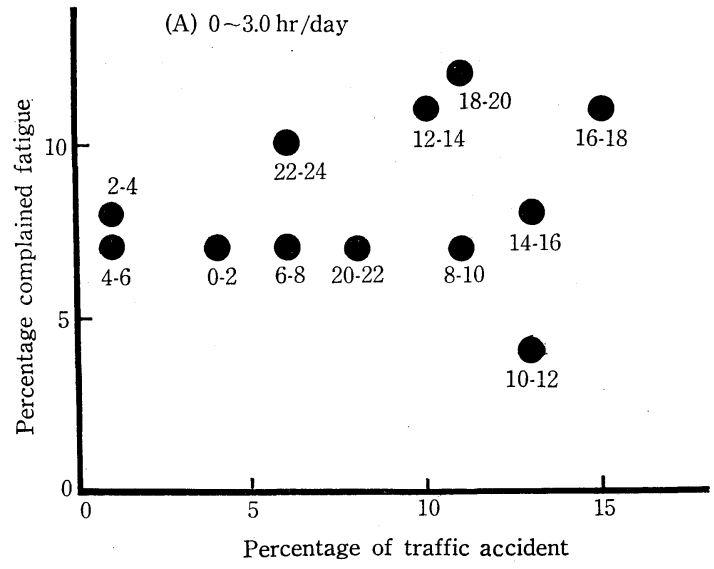

(B) $3.1 \sim 8.0 \mathrm{hr} /$ day
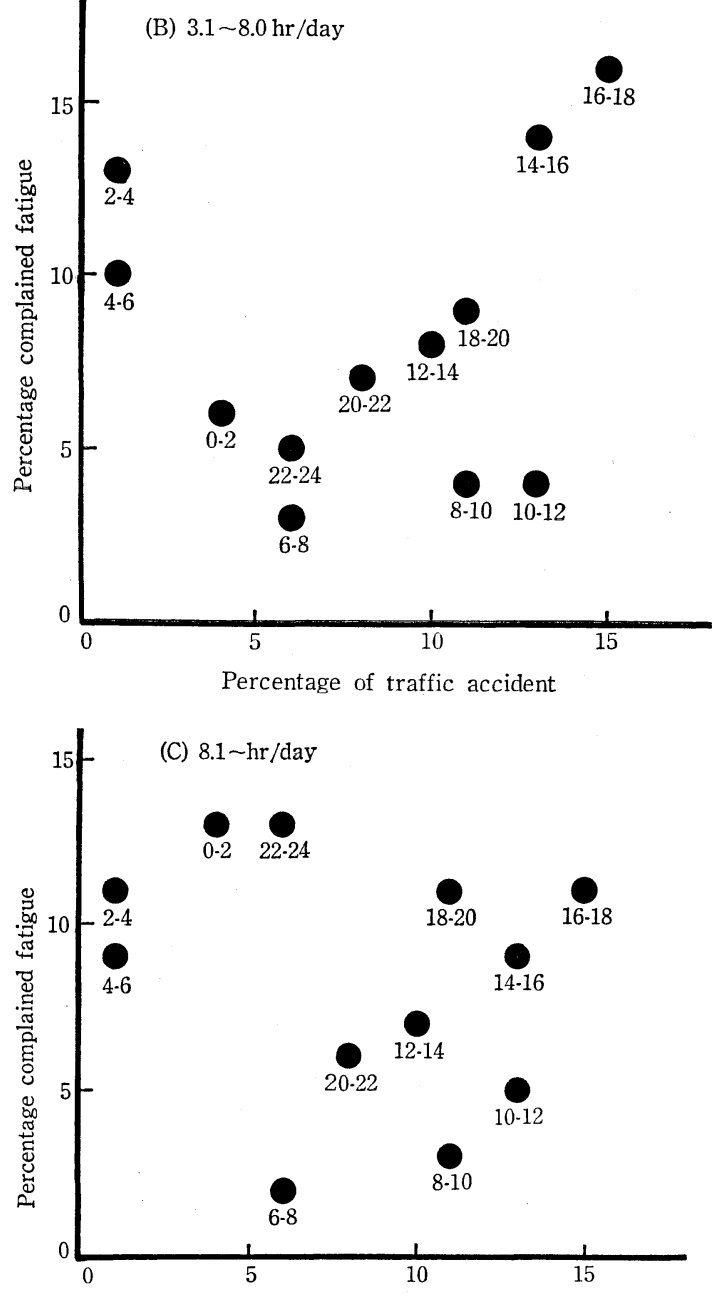

Percentage of traffic accident

Fig. 5 The relation between complained fatigue and traffic accident in each time interval. 
くに少なく，乙れらの時間帯における事故発生には「疲 労」以外の要因がより大きな役割を果たしていると考え られる。すなわち交通状況, 道路条件, 運転条件などを 加えて, さらに, 検討する余地があろう。

短時間運転者の場合, 「疲労」と「事故」との相関は 低いが，運転労㗢時間が短いほど，「眠気」と「事故」 との間にやや相関が高くなる傾向が認めるられた。つま り運転労働時間が長くなると「疲労」之「事故」之の相 関はきわめて高くなり,さらに長くなると, 深夜学働に 㧊ける生理・心理負担が，事故とは別に（このばあい事 故数は少ないが，出合頭などの大きな事故が多い）問題 となる。

さらに, 運転行動之事故についてみると, 事故発生の 確率は「疲労」とくらべて非常に小さいが, 自動車を運 転するかぎり, 交通事故を起てす可能性はある。つまり, 混雑した交通状況之運転行動以外の労働条件に由来する 過度の生理的・心理的負荷が運転時の行動に異常な影響 を及ぼしている ${ }^{6)}$ 。乙れは, 過度の神経緊張の結果とし て, 焦躁感, 眠気, 疲学感などを誘発し, 判断の誤り, 錯覚, 認知の遅れを生み出しているといえる。

運転行動の実態は各々の行動の全体として評洒されね ばならない。というのは, 運転行動の中に, 運転操作そ れ自体以外の回避不可能な日常的行動が意識されるとと なくとられているからである。さらに，運転者の内在的 欲求に上る形, すなわち, 脇見, 喫煙, 杂談, カー・ラ ジオを聞くなどのて長的行動が含まれている。高速運転 研究会8) の調查によれば, たとえばネオン・サインは自 動車運転に不必要な負担を与える妨害要因であるてとが 指摘されており，運転操作が交通環境の影響を多分に受 けていることは確かである。

従来の自動車運転之交通事故の分析は車両行動の範囲 に留まって抢り, 車両行動の決定要因である運転行動に 関する分析は非常に少ない。同時に，現行の事故統計は 交通事故防止対策上というより行政処分上の措置として の性格が強く, 事故統計の問題点は他に指摘される問題 あ少なくない2。本調査の結果からも, 事故統計の指標 を問題にしなければならない。すなわち，運転労働時間 が長いと, 事故は増加するととが判明したが, 運転操作 の熟達度, 交通環境や交通状況の熟知度加らて,「回 数」を指標とするより単位時間当たりの事故回数を指標 とする方が，運転学働時間別にみた運転行動の特性を明 確にしているといえる。

$$
\mathrm{V} \text { 要 約 }
$$

交通事故発生要因の一つである運転行動とその背景の
生活条件である運転学衔時間との関係を, 質問紙法を用 いて, 調査した。その調查対象は交通事故体験者 180 名, ハイタク運転者 44 名, トラック運輪運転者 83 名であっ た。

調査結果は次の通りである。

1）一日当たりの運転労働時間すなわち $0 \sim 3.0 \mathrm{hr} /$ day, $3.1 \sim 8.0 \mathrm{hr} /$ day, $8.1 \sim \mathrm{hr} /$ day には, 運転操作 (ハンドル, ブレーキ, アクセル, クラッチ, チェンジ・ レバー) の差は認められないが 0 3. $0 \mathrm{hr} /$ day は他の条 件に比較し，足による運転操作に「欠点」のある傾向を 示した。

2）長時間運転学㗢者には「運転疲労」と「交通事故 発生回数」との間に高い相関を認め, 一方, 短時間運転 者には,「眠気」と「交通事故発生回数」との間に相関 のある傾向を認めた。

3）しかし，8１0，10１2 時では疲労感は比較的少 ないが（運転行為の影響が大きく）事故が多い。2-4, 4一6時の深夜早朝時には疲学感は大きいが（交通量が少 ないため) 事故は比較的少ない。

4） 12 14, 14 16時の時間帯では, 疲学の訴え, 事 故回数ともに，運転労働時間と関係なく大きい。

5）実数の事故回数より運転単位時間当たりの事故回 数を指標之する方が, 運転学働時間と運転行動との関連 特性を明確にしている。

\section{文献}

1）秋重義治監訳 : 精神測定法, 培風館, 東京 (1961).

2) 田中良久: 心理学的測定法, 東京大学出版会, 東京 (1961).

3）大阪府警：交通事故統計（昭和 44 年 $1 \sim 6$ 月）；大阪 (1969).

4) 大谷璋, 石橋富和: 道路の整備度之運転負担, 大阪 府立公衆衛生研究所研究報告労㗢衛生編, 第 5 号, 31-35 (1967).

5) 細川汀, 中平進一 : トラック運輪労働者の健康之災 害, 日衛誌, 23, 461-469 (1968).

6) 細川汀, 中迫勝, 新井邦子 : 都市タクシ一運転作業 者の労働医学的検討, 日衛誌, 24, 396-412 (1969).

7) 橋本邦衛: 交通と疲労, からだの科学, 22, 78-83 (1968).

8）高速運転研究会: 自動車運転におよぼすネオンサイ ンの影響について, 大阪 (1969).

9) 細川汀 : 交通災害の社会医学的検討, 都市問題講座 V, 汐文社, 京都 (1970).

10) Edwards, A. L.; Statistical methods for the behavioral sciences, Holt, New York (1954). （受付1970年 4 月21日） 